\title{
Study of, Key Role of Bedside, Easy and Cost-Effective, Overnight Rifampicin Test, in Diagnosing Childhood Gilbert Syndrome
}

\author{
Kripa Nath Mishra ${ }^{1}$, Sanjay Kumar Nirala², Anil Kumar ${ }^{3}$ \\ ${ }^{1}$ Department of Paediatrics, Darbhanga Medical College and Hospital, Darbhanga, Bihar, India. ${ }^{2}$ Department of \\ Paediatrics, Darbhanga Medical College and Hospital, Darbhanga, Bihar, India. ${ }^{3}$ Department of Paediatrics, Darbhanga \\ Medical College and Hospital, Darbhanga, Bihar, India.
}

\section{ABSTRACT}

\section{BACKGROUND}

Gilbert syndrome is an autosomal recessive disorder which presents as an asymptomatic unconjugated hyperbilirubinemia where there is decreased hepatic bilirubin uridine diphosphate glucuronyl transferase [UGT] enzyme activity which leads to decreased glucuronidation. Patients of Gilbert syndrome present with mild abdominal discomfort, general fatigue, malaise, and mild jaundice. This syndrome is aggravated by loss of water from the body, hunger, anxiety and weakness due to intercurrent hyperthermic states of body, vigorous exercise and menstruation. Gilbert syndrome disappears without medications and sometimes needs conservative management only. This syndrome usually presents after puberty due to change in sex steroids' concentration which affects bilirubin metabolism.

\section{METHODS}

This case control study includes 16 cases of Gilbert syndrome admitted in child medical ward in Darbhanga Medical College \& Hospital, Laheriasarai, Darbhanga, Bihar from June 2017 to June 2019. 16 healthy individuals were taken as control.

\section{RESULTS}

The mean [standard deviation] indirect bilirubin and total bilirubin level raised from $1.56[0.41] \mathrm{mg} / \mathrm{dl}$ and 2.15[0.49] respectively to $2.52[0.71] \mathrm{mg} / \mathrm{dl}(\mathrm{p}<0.001)$ and $3.23[0.72](\mathrm{p}<0.001)$ respectively after use of Rifampicin and in vigorous subjects from $0.34[0.09] \mathrm{mg} / \mathrm{dl}$ and $0.69[0.13]$ respectively to $0.84(0.23) \mathrm{mg} / \mathrm{dl}$ $(\mathrm{p}<0.001)$ and $1.68[0.56](\mathrm{p}<0.001)$ respectively in patients with Gilbert syndrome. Increase of these levels above the normal threshold level had reduced precision for diagnosis of G.S. However, the total serum bilirubin rising after Rifampicin above 2.4 $\mathrm{mg} / \mathrm{dl}$ was $93.8 \%$ sensitive and $93.3 \%$ specific for diagnosis of G.S. and indirect bilirubin level rising above $1.3 \mathrm{mg} / \mathrm{dl}$ was $100 \%$ sensitive and $100 \%$ specific.

\section{CONCLUSIONS}

Rifampicin increases serum bilirubin level to more than normal in patients of G.S. and healthy individuals also. Overnight Rifampicin test is easy and cost-effective which may be useful in the diagnosis of G.S., if threshold levels for serum total and unconjugated bilirubin level rose above 2.4 and $1.3 \mathrm{mg} / \mathrm{dl}$. However, in patents with Gilbert syndrome with lowered level of UGT accumulations of Rifampicin causes level of total bilirubin to be increased, Rifampicin does not have a direct effect on UGT level in some normal individuals. This study shows that Rifampicin elevates serum bilirubin level 2 hours later in fasting and 4 hours in non-fasting state. Family members should be warned of the possibility of serious jaundice in carers of G.S. under specific circumstances.

\section{KEY WORDS}

G.S., Bilirubin, Hyperbilirubinemia, Rifampicin. UGT, Indirect
Corresponding Author: Dr. Sanjay Kumar Nirala, Junior Resident, Department of Paediatrics, Darbhanga Medical College and Hospital, Darbhanga-846003,

Bihar, India.

E-mail:dr.skn07@gmail.com

DOI: 10.14260/jemds/2019/793

Financial or Other Competing Interests: None.

How to Cite This Article:

Mishra KN, Nirala SK, Kumar A. Study of, key role of, bedside, easy and cost-effective, overnight rifampicin test, in diagnosing childhood Gilbert syndrome. J. Evolution Med. Dent. Sci. 2019;8(49):3667-3670, DOI: $10.14260 /$ jemds/2019/793

Submission 18-06-2019, Peer Review 15-11-2019, Acceptance 22-11-2019, Published 09-12-2019.

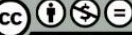




\section{BACKGROUND}

Gilbert Syndrome is a very common autosomal recessive disorder of bilirubin metabolism and was first described by Augustin Nicolus Gilbert and Pierrelerebaullet in 1901, later by Arias. G.S. is an asymptomatic unconjugated hyperbilirubinemia without haemolysis and hepatocellular diseases. ${ }^{1}$ is a minor, prolonged and benign disorder. Gilbert syndrome also known as Meulengracht disease, constitutional hepatic dysfunction or familial non-haemolytic jaundice.

Genetic basis of Gilbert syndrome is low level of hepatic bilirubin uridine diphosphate glucuronyl transferase [UGT] enzyme though there is also role of transport defect in hepatocytes and occult haemolysis ${ }^{2}$. More than 100 mutations have been implicated in causation of Gilbert syndrome but two very common genotypes among Caucasians is the homozygous polymorphism of two extra bases (TA) in TATA box sequence of the promoter region of the UGT1A1 gene. Thus, Gilbert syndrome is due to a common polymorphism, where an additional TA dinucleotide insertion in the promoter region of UGT1A1 leads to reduced binding of TATA binding protein and decreases normal gene activity leading to reduced amount of enzyme production. So, these patients are homozygous for a elongated version of the TATA sequence A [TA]TAA; ${ }^{2,3}$ where its inheritance is autosomal dominance with partial penetrance ${ }^{4}$. Glucuronidation of bilirubin found to be $30 \%$ lower in $\mathrm{G}, \mathrm{S}$ as compared to normal individuals. Genotyping by Snapback primer can differentiate all UGT1A1 promoter genotypes. Glucuronidation of several substrates other than bilirubin like, pharmacological drugs, endogenous hormones, ecological toxins, and aromatic hydrocarbons by UGT1A1 leads to inactivation of these substances, mutation of UGT1A1 gene causes increased risk of cancer and the predisposition to drug toxicity specifically in cancer chemotherapy and episodes of jaundice when exposed to the agents.

Genetic testing is currently available only in research works. Gilbert syndrome usually occours after puberty due to change in the sex steroids concentration which affects the bilirubin metabolism which leads to increased bilirubin level. G S seen more commonly in males due to higher level of of bilirubin.

On histopathological examination the liver appears normal except for mild non-specific accumulation of lipofuscin pigment in the centrilobular zones. There are mild abnormalities which can be seen in electron microscopy. This syndrome is aggravated by loss of water from the body, hunger, anxiety and weakness due to inter current hyperthermic states of body, vigorous exercise, menstruation. Patient presents with mild icterus, tiredness, malaise and mild discomfort in abdomen for which no cause is seen. Abdominal symptoms may have many causes where anxiety is very important. G.S. self-resolving illness where no treatment is needed apart from conservative treatment. About $5-10 \%$ of population with G.S. having total serum bilirubin concentrations ranges from $1-6 \mathrm{mg} / \mathrm{dl}^{5}$

\section{METHODS}

All the participants have given informed consent during registration. Case and Control selected were similar in age and gender. Healthy 16 individuals selected form outpatient department as control and Suspected 16 patients of Gilbert syndrome admitted as cases in child medical ward in Darbhanga medical college \& hospital, Laheriasarai, Darbhanga, Bihar. Institutional ethical committee of Darbhanga medical college \& hospital, laheriasarai, Bihar has approved the student's unpaired t-test case-control study to be started in the institution by Dr. Sanjay Kumar Nirala.

Considering normal liver function test, normal hepatic imaging, normal reticulocyte counts without haemolysis and peripheral blood smear, Gilbert syndrome is diagnosed by the presence of indirect hyperbilirubinemia and with total serum bilirubin $>1.3 \mathrm{mg} / \mathrm{dl}$ on minimum 2 events in earlier 2 years. Cases and controls were allowed to consume normal diet and were limited to take any chemical or herbal medication, liver function test done in fasting [Serum albumin, serum SGOT/AST, serum SGPT/ALT, serum lactate dehydrogenase, serum ALP, serum Bilirubin], reticulocyte count, and peripheral blood smear done on 2 consecutive days. This study shows the action of supervision of rifampicin on serum bilirubin level in healthy subjects and in patients of Gilbert syndrome. All study subjects were given a single oral dose of $600 \mathrm{mg}$ of Rifampicin on earlier night 12 hour before second sampling.

Diazo method has been used to measure serum bilirubin level. Total serum bilirubin level below $1 \mathrm{mg} / \mathrm{dl}$ in $99 \%$ of general population is measured by Diazo method and threshold of $1.2 \mathrm{mg} / \mathrm{dl}$ taken for Student's unpaired t-test were used for comparison purposes.

Before and after using a single oral dose of $600 \mathrm{mg}$ rifampicin in 16 patients of Gilbert syndrome and 16 healthy subjects' serum indirect and total bilirubin level were measured.

\section{Statistical Analysis}

Statistical data analysis has been approved using the Statistical package for the Social Sciences (SPSS) Programme (Chicago version, 11, 5). Student's unpaired t-test has been used for comparisons purposes. P- Value below 0.05 were considered as significant. Recent data shows that the rifampicin test can be used as analytical cost-effective test but there is debate about its action on bilirubin level in patients with GS and in healthy individual. Before and after giving a single oral dose of $600 \mathrm{mg}$ rifampicin in 16 patients of Gilbert syndrome, serum indirect and total bilirubin level has been measured. The mean [Standard deviation] indirect bilirubin ant total bilirubin level raised from $1.56[0.41] \mathrm{mg} / \mathrm{dl}$ and 2.15 [0.49] correspondingly to $2.52[0.71] \mathrm{mg} / \mathrm{dl}(\mathrm{p}<0.001)$ and 3.23 [0.72] $(\mathrm{p}<0.001)$ respectively after use of Rifampicin and in vigorous subjects from $0.34[0.09] \mathrm{mg} / \mathrm{dl}$ and $0.69[0.13]$ respectively to $0.84(0.23) \mathrm{mg} / \mathrm{dl}(\mathrm{p}<0.001)$ and $1.68[0.56](\mathrm{p}<0.001)$ correspondingly in patient with Gilbert syndrome. Increase of these levels above the normal threshold level had reduced precision for diagnosis of G.S. However, the total serum bilirubin rising after Rifampicin above $2.4 \mathrm{mg} / \mathrm{dl}$ was $93.8 \%$ sensitive and $93.3 \%$ specific for diagnosis of G.S. and indirect bilirubin level rising above 1.3 $\mathrm{mg} / \mathrm{dl}$ was $100 \%$ sensitive and $100 \%$ specific. 


\section{Inclusion Criteria}

Assortment of control subjects were done indiscriminately from among healthy populations having normal liver function test with total serum bilirubin $[<1 \mathrm{mg} / \mathrm{dl}]$ on minimum 2 events in previous 2 years without rise after 24 hours of fasting.

\section{Exclusion Criteria}

Subjects having prior history of liver disease, diabetes mellitus, Alcoholism, cholelithiasis, valvar heart disease, congestive heart failure, haemolysis, haemoglobinopathy, Hep-B positive or anti-HCV Test, or has taken any drugs in the last 2 weeks in normal individuals were excluded from study.

\section{RESULTS}

The mean[standard deviation] indirect bilirubin ant total bilirubin level raised from $1.56[0.41] \mathrm{mg} / \mathrm{dl}$ and 2.15 [0.49] correspondingly to $2.52[0.71] \mathrm{mg} / \mathrm{dl} \quad(\mathrm{p}<0.001)$ and $3.23[0.72](\mathrm{p}<0.001)$ respectively after use of Rifampicin and in vigorous subjects from $0.34[0.09] \mathrm{mg} / \mathrm{dl}$ and 0.69 [0.13] respectively to $0.84(0.23) \mathrm{mg} / \mathrm{dl}(\mathrm{p}<0.001)$ and 1.68 [0.56] $(\mathrm{p}<0.001)$ correspondingly in patient with Gilbert syndrome. Increase of these levels above the normal threshold level had reduced precision for diagnosis of G.S.

\begin{tabular}{|c|c|c|}
\hline $\begin{array}{c}\text { Before Rifampicin } \\
\text { Administration (mg/dl)- S.D. }\end{array}$ & $\begin{array}{c}\text { After Rifampicin } \\
\text { Administration (mg/dl)- S.D. }\end{array}$ & $\mathbf{p}$ \\
\hline $2.15[0.49]$ & $3.23[0.72]$ & $<0.001$ \\
\hline $1.56 \quad[0.41]$ & $2.52[0.71]$ & $<0.001$ \\
\hline $\begin{array}{c}\text { Table [A]. Mean [S.D.] Serum total and Indirect Bilirubin Level after } \\
\text { Administration of Drug Rifampicin in Patients with G.S }\end{array}$ \\
\hline
\end{tabular}

\begin{tabular}{|c|c|c|}
\hline $\begin{array}{c}\text { Before Rifampicin } \\
\text { Administration (mg/dl)-S.D. }\end{array}$ & $\begin{array}{c}\text { After Rifampicin } \\
\text { Administration (mg/dl)-S.D. }\end{array}$ & P \\
\hline $0.69[0.13]$ & $1.68[0.56]$ & $<0.001$ \\
\hline $0.34[0.09]$ & $0.84[0.23]$ & $<0.001$ \\
\hline $\begin{array}{c}\text { Table [B]. Mean [S.D.] Serum Total and Indirect Bilirubin Level after } \\
\text { Administration of Drug Rifampicin in Healthy Individuals }\end{array}$ \\
\hline
\end{tabular}

Table [A] and [B] Serum total and indirect bilirubin concentration before and after overnight Rifampicin test in patients and healthy individuals. However, the total serum bilirubin rising after Rifampicin above $2.4 \mathrm{mg} / \mathrm{dl}$ was $93.8 \%$ sensitive and $93.3 \%$ specific for diagnosis of G.S. and indirect bilirubin level rising above $1.3 \mathrm{mg} / \mathrm{dl}$ was $100 \%$ sensitive and $100 \%$ specific.

\begin{tabular}{|c|c|}
\hline $\begin{array}{c}\text { Elevation of Total Serum Bilirubin } \\
\text { after Rifampicin Administration- } \\
\text { if Level Above }\end{array}$ & $\begin{array}{c}\text { Elevation of Indirect Serum } \\
\text { Bilirubin after Rifampicin } \\
\text { Administration- if Level Above }\end{array}$ \\
\hline $2.4(\mathrm{mg} / \mathrm{dl})$ & $1.3(\mathrm{mg} / \mathrm{dl})$ \\
\hline Sensitivity $93.8 \%$ & Sensitivity $100 \%$ \\
\hline Specificity $93.3 \%$ & Specificity $100 \%$ \\
\hline $\begin{array}{r}\text { Table [C]. Serum Total Bilirubin Concentration before and after } \\
\text { Overnight Rifampicin Test in Controls and Patients. }\end{array}$ \\
\hline
\end{tabular}

\section{DISCUSSION}

Crigler-Najjar syndrome type 1 and type 2 like indirect hyperbilirubinemia are autosomal recessive disorder having clinical expression of very severe hyperbilirubinemia on $1^{\text {st }}$ days of life.

Lucey Driscoll Syndrome is acquired indirect hyperbilirubinemia in newborn where inhibiter of UGT enzyme activity is developed from the mother's serum and breast milk jaundice in which the inhibiter of enzyme activity is transmitted to the infant through lactation in healthy person without family history of Gilbert syndrome, the finding of unconjugated hyperbilirubinemia is usually accidental. Various provocative test like fasting and nicotinic acid test were used for the diagnosis of the syndrome. The sensitivity of the test of the test is raised if serum bilirubin level is raised 24 hours of fasting and fasting of longer duration.

The indirect bilirubin level is raised 2-fold in a person who is affected by caloric limitation to about $400 \mathrm{kcal}$ in 24 hours.6,7 Nicotinic acid provocation test has also been used for the diagnosis where following intravenous administration of nicotinic acid, there is a substantial rise in indirect bilirubin, however this test is non-specific and may be positive in indirect hyperbilirubinemia regardless of the cause and therefore is probably of no value in distinguishing Gilbert syndrome from other entities including chronic hepatic disease.

A carrier family member should be warned of the possibility of serious jaundice under specific circumstances as G.S. is genetically transmitted disorder. The fasting and hyperbilirubinemia relationship particularly among fasting moslems with the syndrome [During ramdan] is of great importance.

Once the diagnosis is confirmed, very important aspect of treatment is to reassure patients that the disorder is selflimiting and insignificant that the prognosis regarding this syndrome is very good that they should escape fasting of longer period and that there is no need for further useless medical investigations.

\section{CONCLUSIONS}

Serum bilirubin level is raised by Rifampicin more in G.S. as well as healthy subjects. If threshold levels for serum indirect bilirubin and total bilirubin level of more than 1.3 and 2.4 $\mathrm{mg} / \mathrm{dl}$ are used, then cost effective overnight rifampicin test would be useful in diagnosis of Gilbert syndrome. Our data shows that Rifampicin elevated total and indirect serum bilirubin level in Gilbert syndrome. However, it also elevates serum bilirubin level to more than normal level in vigorous individuals.6,8,9 Studies done earlier had shown that rifampicin can't raise serum bilirubin level more than normal limit in healthy individual, ${ }^{10}$ though, this has been found in about $80 \%$ of healthy persons in our study.

Identification of the illness with no use of any offensive and avoidable testing is more significant step in diagnosis of G.S.11 Rifampicin raises serum bilirubin level in few normal individuals as it induces cytochrome P-450 isoenzyme and plays excretory role in liver at the cellular level. Rifampicin has no direct effect on UGT levels; Rifampicin increases total bilirubin level in patients with Gilbert syndrome though there is low amount of UGT addition.6,10 This study shows that rifampicin raises bilirubin level after 4 hours in non-fasting 
state and after 2 hours in fasting state. So, Total bilirubin level raised in non-fasting sate to $1.5 \mathrm{mg} / \mathrm{dl}$ and in fasting state to $1.9 \mathrm{mg} / \mathrm{dl}$ after 2-6 hours of oral rifampicin gives sensitivity of $90 \%-100 \%$ in analysing G.S. Its specificity for diagnosing G.S. is not very high because it also causes an elevation in level of indirect bilirubin. Thus, this study focused on access overnight rifampicin test as an applied cost-effective and easy test for diagnosis of G.S.

When Gilbert syndrome occurs in combination with other disease like hereditary spherocytosis, glucose-6-phosphatase deficiency, breastfeeding, thalassemia or other conditions which can increase indirect bilirubin levels, they may potentiate the increase in the level of bilirubin level. Although Gilbert syndrome can cause mild to moderate hyperbilirubinemia in neonates in the absence of any superimposed haemolytic disease, it does not cause significant elevation of unconjugated bilirubin in neonates to cause kernicterus. It has however been reported to cause worsening neonatal jaundice when associated with other haemolytic conditions which can lead to kernicterus.

In patients with co-existing disorders with increased bilirubin levels, phenobarbitone can be used to decrease the bilirubin level by inducing the UGTs.

\section{REFERENCES}

[1] Bosma PJ. Inherited disorder of bilirubin metabolism. J Hepatol 2003;38(1):107-17.

[2] Bosma PJ, Chowdhury JR, Bakker C, et al. The genetic basis of the reduced expression of bilirubin UDPglucuronosyltransferase 1 in Gilbert syndrome. N Engl J Med 1995;333(18):1171-5.
[3] Peters WH. Te Morsche RH, Roelofs HM. Combined polymorphisms in UDP- glucuronosyltransferases $1 \mathrm{~A} 1$ and 1A6: implications for patients with Gilbert's syndrome. J Hepatol 2003;38(1):3-8.

[4] Borlak J, Thum T, Landt O, et al. Molecular diagnosis of a familial nonhaemolytic hyperbilirubinemia (Gilbert's syndrome) in healthy subjects. Hepatology 2000;32 (4 Pt 1):792-5.

[5] Kliegman RM. Nelson Text book of paediatrics. Chapter 357. Inherited deficient conjugation of bilirubin. Gilbert syndrome. 20th edn. 2017: p. 1937.

[6] Murthy GD, Byron D, Shoemaker D, et al. The utility of rifampicin in diagnosing Gilbert's syndrome. Am J Gastroenterol 2001;96(4):1150-4.

[7] Thompson R. Genetic transmission of Gilbert's syndrome. In: Okolicsanyi L, edr. Familial hyperbilirubinemia. Chichester: John Wiley 1981: p. 917.

[8] Eradil A, Kadayifci A, Ates Y, et al. Rifampicin test in the diagnosis of Gilbert's syndrome. Int J Clin Pract 2001;55(2):81-3.

[9] Alcubilla VJP, Mauriz GE, Bruna MMS, et al. The rifampicin test in the diagnosis of Gilbert syndrome. Aten Primaria 1993;11(2):84-6. (Spanish)

[10] Gorski JC, Vannaprasaht S, Hamman MA, et al. The effect of age, sex and rifampicin administration on intestinal and hepatic cytochrome P450 3A activity. Clin Pharmacol Ther 2003;74(3):275-87.

[11] Radu P, Atsmon J. Gilbert's syndrome - clinical and pharmacological implications. Isr Med Assoc J 2001;3(8):593-8.

[12] Asensio NA, Manrique MF, Sereno EV, et al. Gilbert's syndrome: comparative study of fasting and rifampicin as diagnostic test. Rev Esp Enferm Apar Dig 1986;69(2):133-5. 